\title{
Changes in abundance of the neon flying squid Ommastrephes bartramii in relation to climate change in the central North Pacific Ocean
}

\author{
Taro Ichii ${ }^{1,6, *}$, Kedarnath Mahapatra ${ }^{2}$, Mitsuo Sakai ${ }^{3}$, Toshie Wakabayashi ${ }^{3}$, \\ Hiroshi Okamura ${ }^{3}$, Hiromichi Igarashi ${ }^{4}$, Denzo Inagake ${ }^{5}$, Yoshihiro Okada ${ }^{2}$
}

\author{
${ }^{1}$ National Research Institute of Far Seas Fisheries, 5-7-1 Orido, Shimizu-ward, Shizuoka-city, Shizuoka 424-8633, Japan \\ ${ }^{2}$ School of Marine Science and Technology, Tokai University, 3-20-1 Orido, Shimizu-ward, Shizuoka-city, Shizuoka 424-8610, \\ Japan \\ ${ }^{3}$ National Research Institute of Far Seas Fisheries, 2-12-4 Fukuura, Kanazawa-ward, Yokohama-city, Kanagawa 236-8648, Japan \\ ${ }^{4}$ Data Research Center for Marine-Earth Sciences, JAMSTEC, 3173-25, Showa-machi, Kanazawa-ward, Yokohama-city, \\ Kanagawa 236-0001 Japan \\ ${ }^{5}$ National Research Institute of Fisheries Science, 2-12-4 Fukuura, Kanazawa-ward, Yokohama-city, Kanagawa 236-8648, Japan
}

${ }^{6}$ Present address: Fisheries Agency, 1-2-1 Kasumigaseki, Chiyoda-ward, Tokyo 100-8907, Japan

\begin{abstract}
Interannual changes in abundance of the autumn cohort of neon flying squid Ommastraphes bartramii during 1979 to 2006 were examined in relation to the large-scale climate shift in the central North Pacific Ocean. Catch per unit of effort (CPUE) of driftnet surveys, which is assumed to reflect the squid stock level, was very low during 1999 to 2002, which was an anomalous climate period. Given that the autumn cohort uses productive areas near and north of the transition zone chlorophyll front (TZCF) as favorable nursery and feeding grounds, we examined 3 covariates - (1) the winter position of the TZCF in the neon flying squid nursery ground, (2) the summer position of the TZCF in the feeding ground and (3) fishing mortality - to estimate which covariates were significantly correlated with low CPUE time periods. Multiple linear regression analysis suggested that only the effect of winter position of the TZCF in the nursery ground best predicted the change in the CPUE. The anomalous climate conditions caused a significant reduction in net primary production over an extended area within the subtropical frontal zone (STFZ), which is the main nursery ground for the autumn cohort. Hence, we assume that food availability for juvenile neon flying squid could be critical for the level of stock recruitment of this cohort. Furthermore, the sea level anomaly (SLA), which is considered to be a useful index of variability in the upper ocean structure, significantly correlated to the CPUE during spawning and nursery periods in the STFZ. Our study supports the hypothesis that the bottom-up effect of the climate shift can be manifested rapidly in neon flying squid, indicating that squid abundance can act as a productivity integrator and a real-time ecosystem indicator that respond to large-scale environment changes.
\end{abstract}

KEY WORDS: Neon flying squid · Climate shift $\cdot$ Transition zone chlorophyll front $\cdot$ Net primary productivity $\cdot$ Subtropical Frontal Zone $\cdot$ Bottom-up effect $\cdot$ Marine ecosystem

\section{INTRODUCTION}

Ommastrephid squid, which are linked to basinscale oceanic circulation, are characterized by large and unpredictable interannual fluctuations in abundance, and stock recruitment relationships are poorly known (Bakun \& Csirke 1988). The changes in ommastrephid squid abundance are often related to 
large-scale climate shifts (e.g. Sakurai et al. 2000, Waluda et al. 2001). Understanding the ommastrephid population dynamics in relation to climate change is important to determine potential oceanographic factors responsible for changes in their stock levels. So far, however, limited data on climate-related changes in abundance have been available for large muscular ommastrephid squid (e.g. Dosidicus, Ommastrephes, Sthenoteuthis), which are predominant in various oceanic ecosystems (Jackson \& O'Dor 2007). Hence, in this study we examined interannual changes in abundance of the autumn cohort of neon flying squid Ommastrephes bartramii (also known as red flying squid) during the period from 1979 to 2006 in relation to the large-scale climate changes in the North Pacific Ocean to elucidate bottom-up effects of climate changes on this species.

The neon flying squid is an oceanic squid that occurs worldwide (Roper et al. 1984, Bower \& Ichii 2005), and the North Pacific population comprises an autumn spawning cohort and a winter-spring spawning cohort (Yatsu et al. 1997, 1998). Both cohorts migrate between spawning grounds in subtropical waters and feeding grounds in subarctic waters within a $1 \mathrm{yr}$ life span (Fig. 1) (Yatsu et al. 1997, 1998, Murata \& Nakamura 1998, Chen \& Chiu 2003). The autumn cohort corresponds to a group of large-sized individuals (LL in
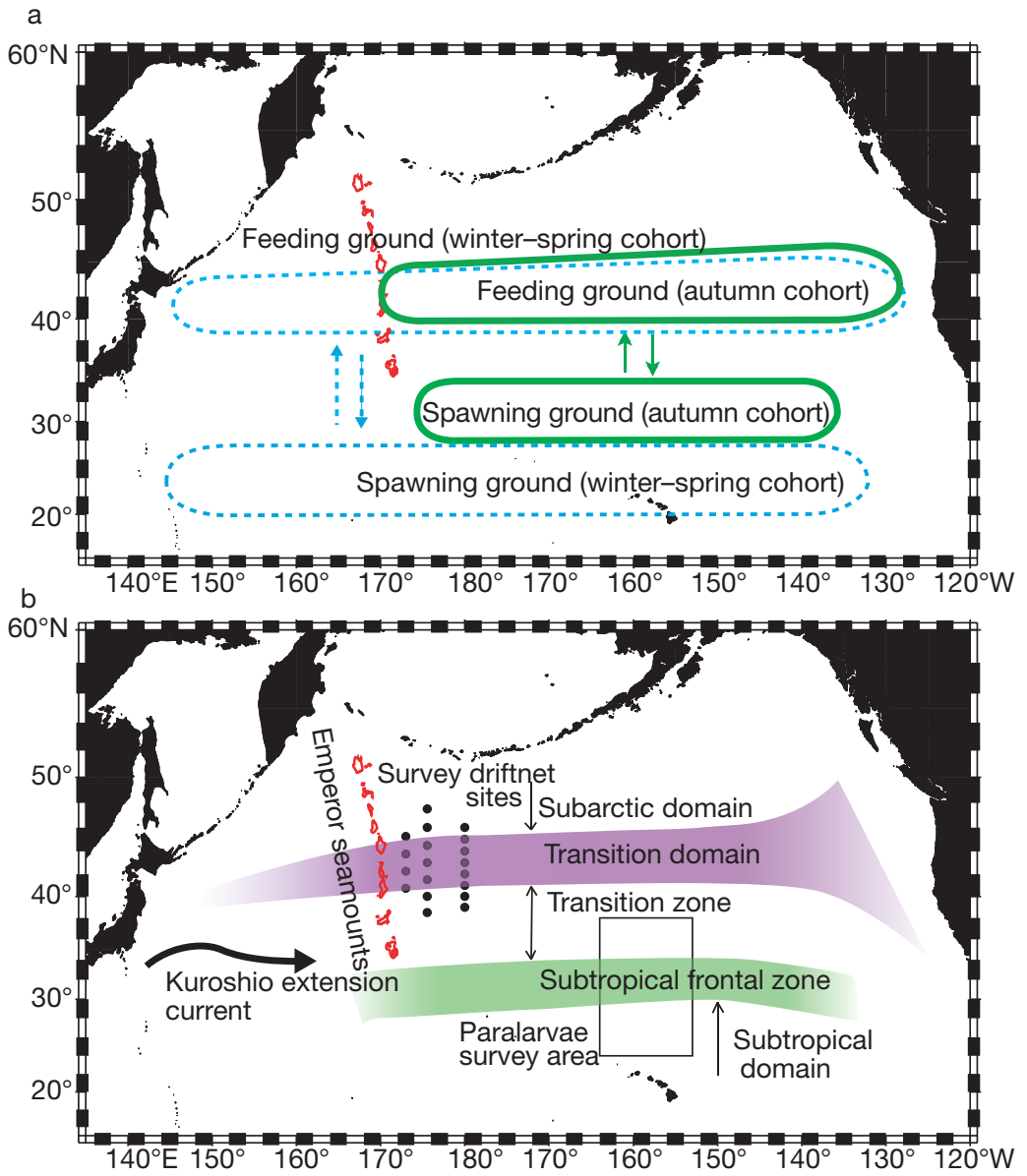

Fig. 1. Ommastraphes bartramii. (a) Migration patterns of the autumn and winter-spring cohorts of neon flying squid and (b) survey areas and major oceanographic regions in the North Pacific Ocean. Solid circles and rectangle in panel (b) indicate locations of survey driftnet sites and paralarvae survey area, respectively. Red: seamounts

Murata 1990) that grows fast during the first half of its life cycle, while the winter-spring cohort corresponds to a group of small-sized individuals (L, S and SS in Murata 1990) that grows fast during the second half. This difference in growth patterns between the 2 cohorts can be explained by different schedules in their use of the food-rich habitat during their life cycle. The main spawning and nursery ground for the autumn cohort occurs in the subtropical frontal zone (STFZ), which is characterized by enhanced productivity in winter, whereas the spawning and nursery ground for the winter-spring cohort occurs within the subtropical domain (SD), which is less productive (Fig. 1) (Ichii et al. 2009).

The autumn cohort of neon flying squid is abundant in the central and eastern North Pacific Ocean (Fig. 1) (Yatsu et al. 1998, Ichii et al. 2009). This cohort was the main target of a large-scale driftnet fishery conducted in the international high seas $\left(170^{\circ} \mathrm{E}\right.$ to $\left.145^{\circ} \mathrm{W}\right)$ with annual catches of 100000 to 210000 t during 1979 to 1992 (Yatsu et al. 1993, Ichii et al. 2006). Since a moratorium was imposed on the use of large-scale driftnets, the autumn cohort has been targeted by a jig fishery, with annual catches generally $<50000$ t (Fig. 2).

The stock abundance of the autumn cohort was monitored with survey driftnet data of more than 25 yr. The survey catch per unit of effort (CPUE) was generally low during the period of intensive commercial driftnet fishing (1979 to 1992) (Fig. 2). CPUE showed a remarkable increase after the closure of the driftnet fishery (Yatsu et al. 2000, Ichii et al. 2006). During the period from 1999 to 2002, however, the CPUE was notably low (Fig. 2). This period coincided with anomalous climate conditions in the atmosphere and ocean over the North Pacific owing to a northeastward displacement of the Aleutian Low (Peterson \& Schwing 2003, Minobe 2004). 


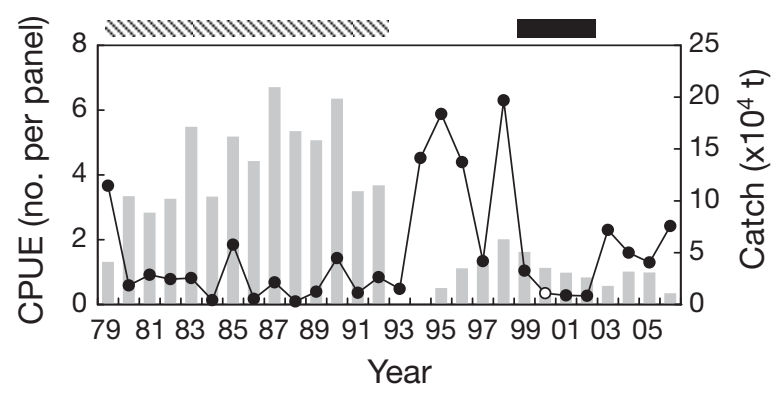

Fig. 2. Ommastraphes bartramii. Interannual variation in survey driftnet CPUE (no. individuals per driftnet panel, black line) and commercial driftnet catch (grey bars) of the autumn cohort of neon flying squid. Hatched and black horizontal bars indicate the squid driftnet fishery period (1979 to 1992) and the anomalous climate condition period (1999 to 2003), respectively. The CPUE during 2000 was estimated (see text) and, hence, shown as an open circle

Bograd et al. (2004) reported that the anomalous oceanic conditions during 1999 to 2002 were depicted by interannual variability in the wintertime southern extent of the transition zone chlorophyll front (TZCF). The TZCF, which is indicated by the $0.2 \mathrm{mg} \mathrm{m}^{-3}$ surface chlorophyll a ( $\mathrm{chl}$ a) concentration contour, is a biologically important feature that separates nutrient-rich subpolar waters from oligotrophic waters across the North Pacific basin (Polovina et al. 2000, 2001, Baker et al. 2007). The TZCF annually migrates over $1000 \mathrm{~km}$ in latitude, influencing productivity in the STFZ during winter and the transition domain (TD) during summer (Bograd et al. 2004). The TZCF is an important migratory and foraging ground for a number of marine species, such as Hawaiian monk seals Monachus schauinslandi, loggerhead sea turtles Caretta caretta, albacore tuna Thunnus abalunga and the crown-of-thorns starfish Acanthaster planci (Polovina \& Howell 2005). Interannual variability in the positions and strength of the TZCF could be influential in the distribution and survival of these species. The autumn cohort of the neon flying squid uses productive areas near and north of the TZCF as favorable nursery and feeding grounds (Ichii et al. 2004, 2009). We examined, therefore, changes in the CPUE in relation to interannual variability of the TZCF position as well as the influence of commercial jigging catch variability to illustrate a possible link between the anomalous oceanographic condition and lower stock level of this cohort during 1999 to 2002.

Furthermore, to understand changes in the autumn cohort stock level of neon flying squid in relation to physical oceanographic dynamics on the basin-wide scale of the North Pacific, we derived the dominant spatial and temporal orthogonal functions applying empirical orthogonal function (EOF) analysis on the multisatellite sea level anomaly (SLA), which is considered to be a useful index of variability in the upper ocean structure. We also carried out correlation analysis between SLA and the stock levels.

\section{MATERIALS AND METHODS}

\section{Satellite data}

Satellite-derived data were used to study interannual variability of sea surface temperature (SST) from 1985 to 2006), SLA from 1993 to 2006, chl a concentrations and net primary production (NPP) from 1997 to 2006 in the North Pacific Ocean. Monthly average SST data were compiled from the Advanced Very High Resolution Radiometer (AVHRR) Pathfinder v. 5.0 data sets produced by the Physical Oceanography Distributed Active Archive Center (PO.DAAC) at the NASA Jet Propulsion Laboratory (podaac.jpl.nasa.gov/pub/documents/dataset_docs/ avhrr_pathfinder_sst_v5.html) with a spatial resolution of ca. $0.25^{\circ}$ for both latitude and longitude. The SLA data used in this study are monthly products merged from multisatellite data produced by the CLS Space Oceanography Division as part of the Environment and Climate EU ENACT project (EVK2CT2001-00117) and provided by Archiving Validation and Interpretation of Satellite Data in Oceanography (AVISO) with $0.33 \times 0.33^{\circ}$ spatial resolution on a mercator grid. For EOF analysis and deriving correlation between SLA and stock level under the present study, these data were converted into a $4^{\circ} \times 4^{\circ}$ grid by applying a median filter with a $4^{\circ}$ smoothing window for removing small-scale fluctuations such as mesoscale eddies. The SLA data are the difference between the observed sea surface height (SSH) and the 7 yr mean profile (1993 to 1999), which can be used to monitor upper ocean variability due to mesoscale circulation, seasonal variation or El Niño. (www.aviso.oceanobs.com/en/data/products/ sea-surface-height-products/global/index.html).

The chl a data were derived by mapping the binned monthly files of the reprocessed v. 5.2 of Seaviewing Wide Field-of-view Sensor (SeaWiFS) data (Feldman \& McClain 2007) to an equidistant cylindrical projection with $27 \mathrm{~km}$ resolution (ca. $0.25^{\circ}$ ) at the equator.

Monthly NPP were estimated by the Vertically Generalized Production Model (VGPM) (Behrenfeld \& Falkowski 1997) by using the $0.25^{\circ}$ spatial resolu- 
tion v. 5.2 SeaWiFS chl $a$, cloud-corrected incident photosynthetically active radiation (PAR) and AVHRR SST data. Euphotic depths used for NPP estimation were calculated from SeaWiFS chl a data as described by Morel \& Berthon (1989). To examine the distribution of interannual anomalies of NPP, we used the difference between the monthly average values of 2 periods of interest, i.e. high/medium stock regime and low stock regime of the neon flying squid. The Generic Mapping Tools (GMT) software package was used to produce contour lines depicting the distribution of anomalies of NPP.

\section{Paralarval data for the neon flying squid}

To reveal the spawning and nursery ground for neon flying squid in relation to yearly variation in oceanographic structure, we examined the distribution and abundance of paralarvae of this species during autumn in 1997, 2001, 2002 and 2003 along 4 or 5 longitudinal transects, at 30 to 90 nautical mile intervals, between $155^{\circ}$ and $164^{\circ} \mathrm{W}$ and between $24^{\circ}$ and $37^{\circ} \mathrm{N}$ that passed through the transition zone (TZ), STFZ and SD (Fig. 1). As paralarvae of this species are distributed near the sea surface throughout the day (Young \& Hirota 1990, Saito \& Kubodera 1993, Saito 1994, Bower 1996), horizontal surface towing was conducted with a ring net $(2 \mathrm{~m}$ diameter, $526 \mu \mathrm{m}$ mesh size) at a speed of ca. 2 knots for 20 min. Collected paralarvae of the family Ommastrephidae were identified into species by morphological characteristics (Harman \& Young 1985, Young \& Hirota 1990) and/or a molecular method (Wakabayashi et al. 2006).

To reveal the oceanographic structure, a CTD cast was made at each towing station. The GMT software package was used to produce contour lines depicting the distribution of sea surface temperature and salinity and the distributions of vertical profiles of temperature and salinity in the spawning ground.

\section{Driftnet survey data}

To reveal interannual changes in abundance of neon flying squid, we examined catch data from driftnet surveys conducted in subarctic waters initially by Hokkaido University (HU) from 1979 to 1999 (Hokkaido University 1980-2000) and recently by the National Research Institute of Far Seas Fisheries (NRIFSF) from 2001 to 2006. The data were collected annually from July to August at nearly fixed sites along primarily a $175^{\circ} 30^{\prime} \mathrm{E}$ longitudinal transect between $38^{\circ} 30^{\prime}$ and $47^{\circ} 30^{\prime} \mathrm{N}$ and also along $180^{\circ}$ longitudinal transects between $39^{\circ} 00^{\prime}$ and $46^{\circ} 00^{\prime} \mathrm{N}$ during 2 yr (Table 1) that passed through the subarctic domain, transition domain and TZ (Fig. 1). The neon flying squid occurred in latitudinal range of 40 to $46^{\circ} \mathrm{N}$ in the study region and, hence, the data collected from this latitudinal range were used to calculate survey CPUEs. At each driftnet site, 49 to 134 net panels were deployed in the evening and retrieved the following morning at sunrise. Each panel was $50 \mathrm{~m}$ long and $7 \mathrm{~m}$ deep. Survey driftnets used by HU comprised commercial mesh nets (stretched mesh size: 112 to $118 \mathrm{~mm}$ ) and non-sizeselective nets (18 mesh sizes from 19 to $157 \mathrm{~mm}$, see Takagi 1975). Driftnets used by the NRIFSF comprised commercial mesh nets (115 mm mesh) and nonselective nets (12 mesh sizes from 48 to $157 \mathrm{~mm}$ ).

The autumn cohort of neon flying squid, which are defined as individuals with a mantle length (ML) $\geq 34 \mathrm{~cm}$ (Ichii et al. 2004), was examined. Since they were effectively collected by using mesh sizes of 93 to $157 \mathrm{~mm}$, their stock abundance indices (survey CPUEs) were calculated as the number of individuals per driftnet panel $(50 \mathrm{~m})$ of these mesh sizes.

The driftnet survey was not conducted in 2000. Hence, we estimated survey CPUE in 2000 by means of a linear regression between the survey CPUE $\left(y_{1}\right.$, no. individuals per net panel) and Japanese commercial jigging CPUE $\left(x_{1}, t\right.$ vessel $\left.{ }^{-1} \mathrm{~d}^{-1}\right)$ for the autumn cohort during 1996 and 2002. For this statistical

Table 1. Ommastraphes bartramii. Locations and periods of the driftnet survey for neon flying squid

\begin{tabular}{|c|c|c|c|c|}
\hline Longitude & Year & Date & Latitude & $\begin{array}{l}\text { Station interval } \\
\text { (nautical miles) }\end{array}$ \\
\hline $173^{\circ} \mathrm{E}^{\mathrm{a}}$ & 2003 & $10 \mathrm{Jul}$ to $22 \mathrm{Jul}$ & $40^{\circ} 45^{\prime}$ to $46^{\circ} 25^{\prime} \mathrm{N}$ & 90 \\
\hline $175^{\circ} 30^{\prime} \mathrm{E}$ & 1979-1999, 2001-2002, 2004-2006 & $12 \mathrm{Jul}$ to $8 \mathrm{Aug}$ & $38^{\circ} 30^{\prime}$ to $47^{\circ} 30^{\prime} \mathrm{N}$ & 90 \\
\hline $180^{\circ}$ & $1979-1980$ & $12 \mathrm{Jul}$ to 6 Aug & $39^{\circ} 00^{\prime}$ to $46^{\circ} 00^{\prime} \mathrm{N}$ & 60 \\
\hline
\end{tabular}


analysis, CPUE data were natural log (ln) transformed to satisfy the assumption of normality and homogenous variance. This linear regression equation is expressed as $\ln \left(y_{1}\right)=2.1931 \ln \left(x_{1}\right)-1.65\left(\mathrm{r}^{2}=\right.$ 0.80, p $<0.05$; Fig. 3).

\section{Commercial catches}

We constructed interannual commercial catch data by including newly reported Chinese jigging fishery catch during 1995 and 2005 (Chen et al. 2008, Cao et al. 2009) to the total catch by other nations (Ichii et al. 2006). Since more than $80 \%$ of the Chinese jigging catches are reported to be from the western winterspring stock, we assume that $20 \%$ of those are from the autumn cohort in our study area.

\section{Statistical analysis}

We evaluated potential factors that should be important for interannual changes in the survey CPUE by using multiple linear regression analysis. Favorable nursery and feeding grounds for the autumn cohort are associated with the productive area near and north of the TZCF (Ichii et al. 2004, 2009). We considered the following 3 potential factors: (1) southernmost latitude of the TZCF in winter, which

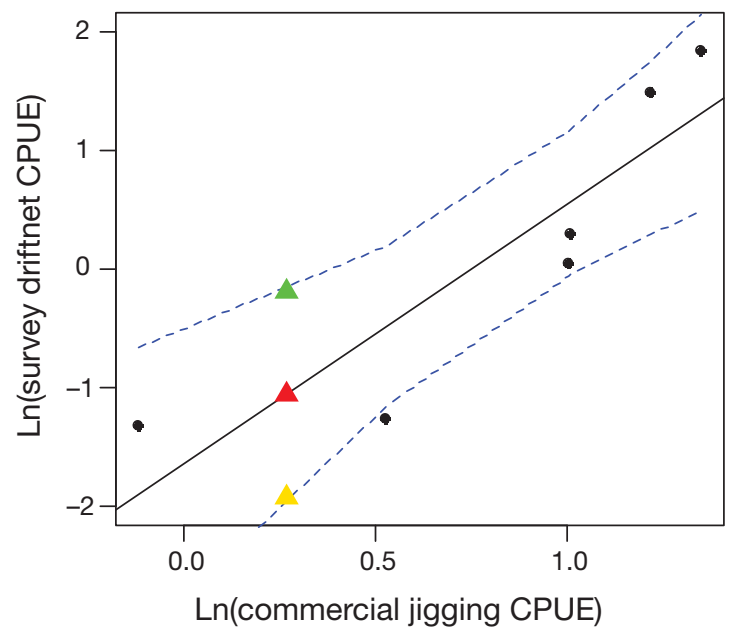

Fig. 3. Ommastraphes bartramii. Relationships between survey driftnet CPUE (no. individuals per driftnet panel) and Japanese commercial jigging CPUE ( $\mathrm{t}_{\text {vessel }}{ }^{-1} \mathrm{~d}^{-1}$ ) during 1996 and 2002. CPUE data were $\ln$ transformed [n(CPUE)] to satisfy the assumptions of normality and homogenous variance. Estimated value for the survey driftnet CPUE for 2000 was shown by a red triangle together with upper $95 \%$ (green triangle) and lower $5 \%$ (yellow triangle) limit of its CI influences productivity in the spawning/nursery ground (juvenile period), (2) northernmost latitude of the TZCF in summer, which influences productivity in the feeding ground (adult period), and (3) commercial jigging catches. Bograd et al. (2004) estimated long-term variability in TZCF position for the period from 1960 to 2003 by using the latitude of the $18^{\circ} \mathrm{C}$ SST isotherm (a proxy for the TZCF) averaged over the region bounded by $160^{\circ} \mathrm{W}$ and $180^{\circ}$ in the North Pacific Ocean. We examined the relationship between the survey $\ln$ (CPUE) and the potential factors during 1994 to 2003 as this period corresponded to when the time series data of the proxy of the TZCF is available (Bograd et al. 2004) and there was no effect of the large-scale commercial driftnet fishery (from 1994 onward, Yatsu et al, 2000), which made this relationship appropriate to illustrate a possible link between the anomalous oceanographic condition and lower stock level.

We used first-order autoregressive models to remove some of temporal autocorrelation and compared all possible models. For example, the full model is:

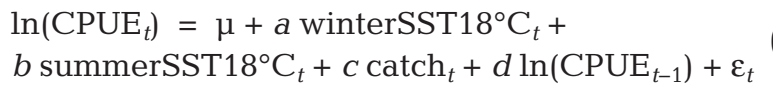

where $\mu, a, b, c$ and $d$ are model parameters, $\mathrm{CPUE}_{t}$ is CPUE in year $t$, winterSST $18^{\circ} \mathrm{C}_{t}$ is the southernmost latitude of the $\mathrm{SST} 18^{\circ} \mathrm{C}$ in winter of year $t$, summerSST $18^{\circ} \mathrm{C}_{t}$ is northernmost latitude of the $\mathrm{SST} 18^{\circ} \mathrm{C}$ in summer of year $t_{1} \operatorname{catch}_{t}$ is commercial jigging catches ( $\mathrm{t}$ ) of year $t$ and $\varepsilon_{t} \approx \mathrm{N}\left(0, \sigma^{2}\right)$, where $\sigma^{2}$ is the variance of the error term. The best model was selected by using the Akaike's information criterion corrected for small sample size $\left(\mathrm{AIC}_{\mathrm{c}}\right)$ (Burnham \& Anderson 2002). In case of models with a first-order autoregressive process, the CPUE datum of the first year $(t=1)$ is not used since the models require CPUE data of year $t-1$, as shown in Eq. (1).

When it was determined that a first-order autoregressive process did not improve the fit of the model, we used multiple linear regression models without the autoregressive term and compared all possible models. For example, the full model is:

$$
\begin{aligned}
& \ln \left(\mathrm{CPUE}_{t}\right)=\mu+\mathrm{a} \text { winterSST } 18^{\circ} \mathrm{C}_{t}+ \\
& b \text { summerSST } 18^{\circ} \mathrm{C}_{t}+C \operatorname{catch}_{t}+\varepsilon_{t}
\end{aligned}
$$

The number of data used is increased by one (i.e. the whole data are used) compared with first-order autoregressive models since the CPUE of the first year is used in the nonautoregressive models.

The CPUE data point for 2000 was estimated from the linear regression between the survey CPUE and 
Japanese commercial jigging CPUE. Hence, we tested the influence of this data point on statistical inferences with 2 methods. Firstly, we used 95\% upper and $5 \%$ lower limits of the confidence interval (CI) for the estimated value of 2000 in multiple regression analysis. Secondly, we excluded the data for 2000 from multiple regression analysis.

The $\ln$ (CPUE) data were correlated with spatially averaged SLA in the main spawning and nursery grounds of the autumn cohort (i.e. 30 to $34^{\circ} \mathrm{N}, 172^{\circ} \mathrm{E}$ to $140^{\circ} \mathrm{W}$ ) during spawning and nursery periods (October to March) to understand the statistical relationship between upper ocean condition and variability in stock level.

\section{EOF analysis}

We performed EOF analysis by using time series of multisatellite SLA data from January 1993 to December 2006 to derive the dominant spatial features and corresponding temporal variability in the upper portion of the entire North Pacific Ocean $\left(20\right.$ to $56^{\circ} \mathrm{N}$, $120^{\circ} \mathrm{E}$ to $\left.100^{\circ} \mathrm{W}\right)$. By applying the EOF analysis, it is possible to extract a small number of principal com- ponents to explain most of the dominant variations from a large data set. To identify the dominant mode of the interannual variability in SLA, we used the monthly anomalies standardized by subtracting the climatological mean for each calendar month for the EOF calculation. The EOF analysis in this study is based on the temporal covariance matrix, without any normalization.

\section{RESULTS}

\section{Distribution of paralarval neon flying squid}

Paralarvae of neon flying squid were mostly distributed in the optimum spawning zone defined by SST of 21 to $25^{\circ} \mathrm{C}$ (Bower 1994, Ichii et al. 2004), the position of which shows seasonal north to south movement. Within this SST range, high abundances ( $\geq 10$ squid per 20 min tow) of paralarvae tended to occur in and around the STFZ defined by the salinity range of 34.6 and 35.2 at $0 \mathrm{~m}$ at ca. 29 and $34^{\circ} \mathrm{N}$, respectively, in all 4 years (Fig. 4). The latitudinal position of STFZ did not show distinct interannual variability among the survey years, even between

(a) Surface temperature
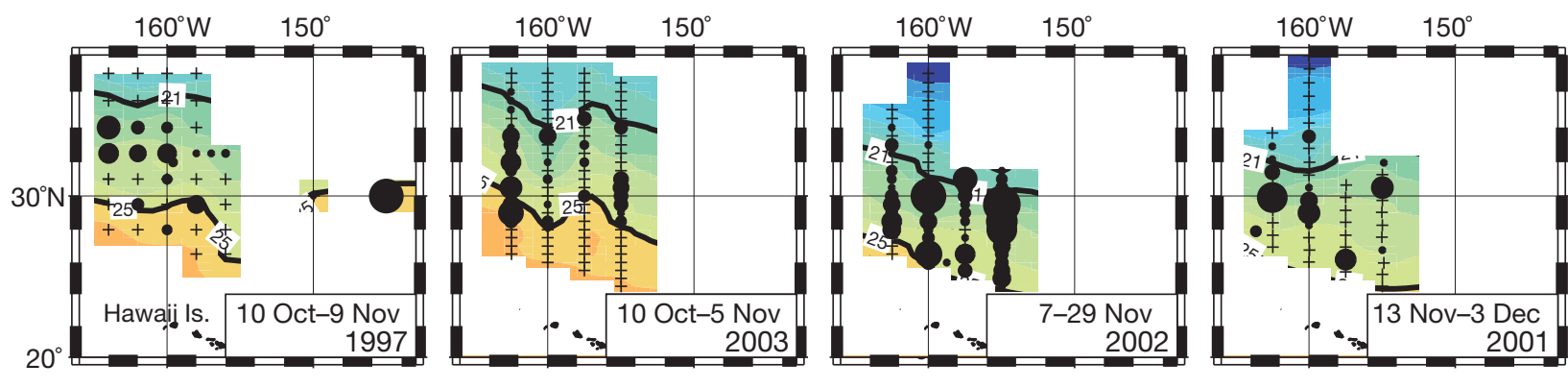

(b) Surface salinity
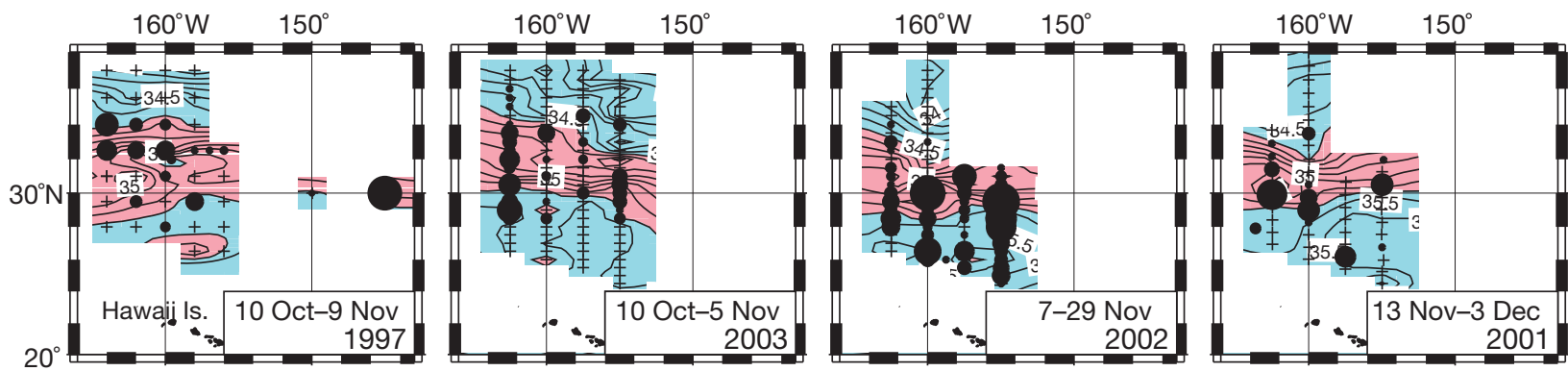

Fig. 4. Ommastraphes bartramii. Distribution of paralarval neon flying squid in relation to (a) sea surface temperature (SST) and (b) surface salinity during autumns of 1997, 2001, 2002 and 2003. Densities of paralarvae were standardized as number of individuals per 20 min surface tow using a ring net ( $2 \mathrm{~m}$ diameter). The SST range of 21 to $25^{\circ} \mathrm{C}$ in (a) corresponds to the optimum spawning ground for this species (Bower 1994, Ichii et al. 2004). Pink colored zone in (b) corresponds to the subtropical frontal zone (surface salinity 34.6 to 35.2 ; Roden 1991) 
high/medium stock hatching years (1997, 2002 and 2003) and a low stock hatching year (2001).

The STFZ is characterized with distinct oceanographic features; the cooler and less saline water from the north sank below the warmer and higher saline water to the south, resulting in the formation of salinity fronts near the surface and subsurface (Fig. 5). The proximity of paralarvae abundance to the front location suggests that the main autumn spawning ground was associated with the STFZ and its vicinity. Paralarval neon flying squid remained in the STFZ and used it as a nursery ground during winter (Ichii et al. 2009).

\section{Multiple linear regression}

In the analysis incorporating a first-order autoregressive process, the model with the smallest $\mathrm{AIC}_{\mathrm{c}}$ values (i.e. the best model) included only a single predictor of winterSST $18^{\circ} \mathrm{C}_{t}$, i.e.:

$$
\ln \left(\mathrm{CPUE}_{t}\right)=\mu+a \text { winterSST } 18^{\circ} \mathrm{C}_{t}+\varepsilon_{t}
$$

The value of $\Delta \mathrm{AIC}_{\mathrm{C}}$, which is the difference between the best model and other models that include the pre- dictor of $\mathrm{CPUE}_{t-1}$, was greater than 2.0 (the minimum value was 2.5) (Table 2). Differences in $\mathrm{AIC}_{\mathrm{c}}$ greater than 2 are generally considered to be significant (Burnham \& Anderson 2002). Thus, modeling the coherent year effect as a first-order autoregressive process did not improve the predictability of the model.

We then used the model without an autoregressive term to evaluate potential factors influencing stock level. The $\mathrm{AIC}_{\mathrm{c}}$ best model included only one predictor, i.e. winterSST $18^{\circ} \mathrm{C}_{t} . \Delta \mathrm{AIC}_{\mathrm{c}}$ between the best and the second-best model (null model) was greater than 2.0 (the minimum value was 2.3) (Table 3). The coefficient of winterSST $18^{\circ} \mathrm{C}_{t}$ for the best model was -0.776 $(\mathrm{SE}=0.283)$. Thus, winterSST $18^{\circ} \mathrm{C}_{t}$ had a significant effect on the CPUE, but summerSST $18^{\circ} \mathrm{C}_{t}$ and catch were insignificant as predictors for the change of CPUE. This suggests that winterSST $18^{\circ} \mathrm{C}_{t}$ is an important determinant of stock level. It was apparent that the CPUE was extremely low during 1999 to 2002, when the $18^{\circ} \mathrm{C}$ SST remained anomalously northward (i.e. north of $31^{\circ} \mathrm{N}$ ) in the nursery ground (Fig. 6).

With regard to the influence of the data point for 2000 on statistical inferences, when we used $95 \%$ upper and $5 \%$ lower limits of the CI for the estimated value of 2000, the CI covered almost all data points

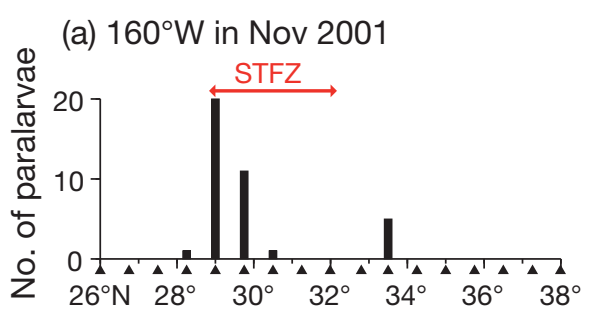

(b) $160^{\circ} \mathrm{W}$ in Nov 2002

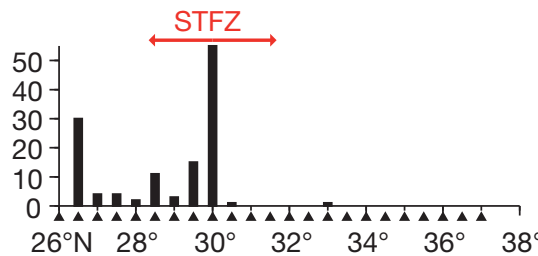

(c) $162.5^{\circ} \mathrm{W}$ in Oct 2003
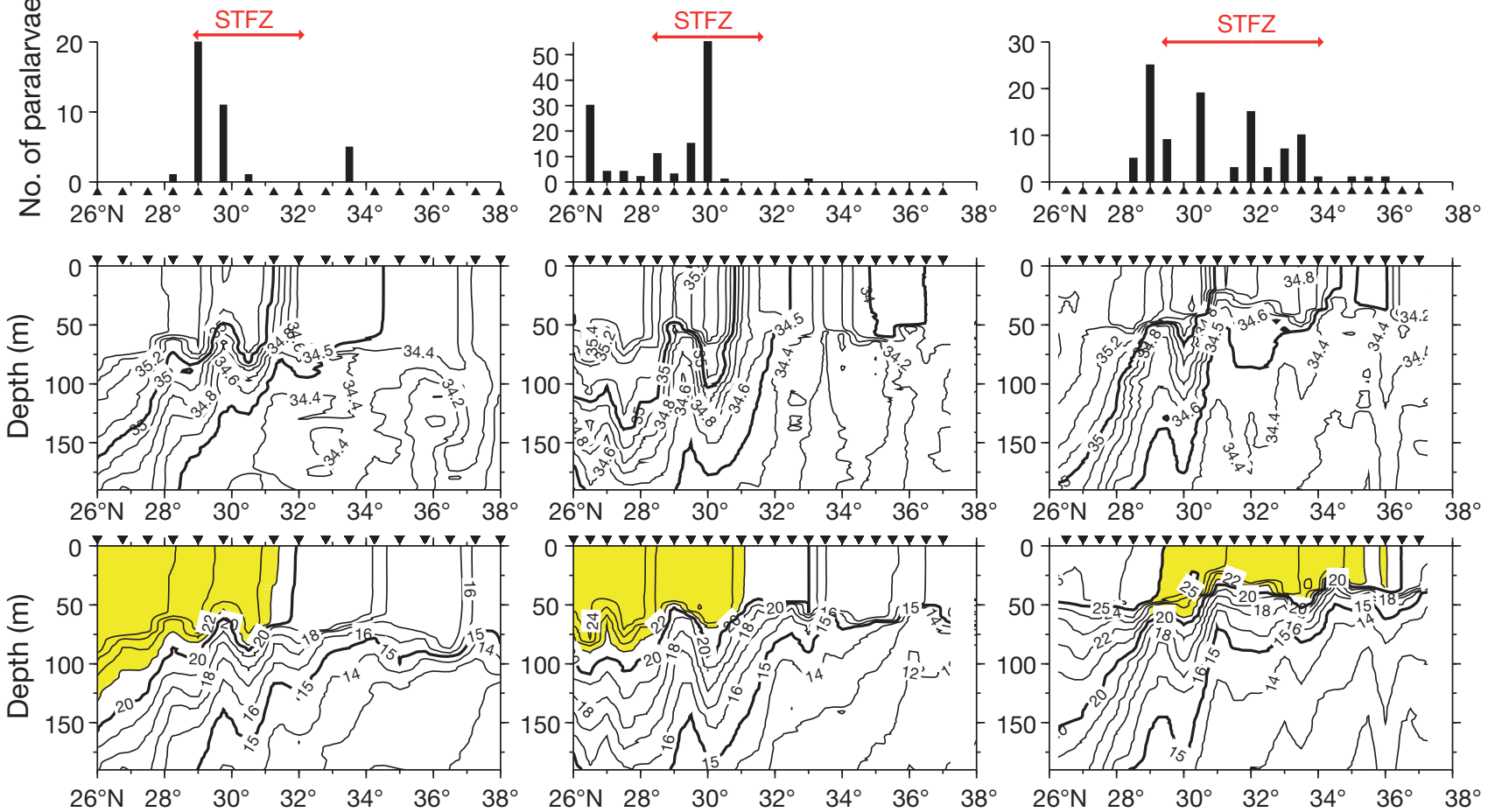

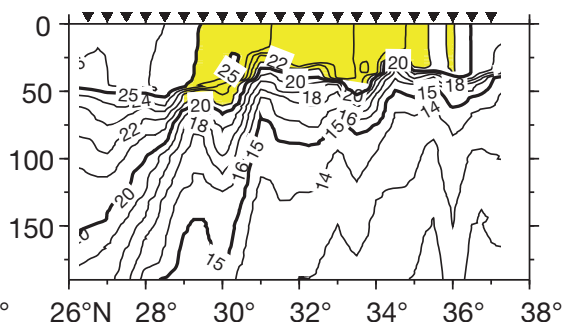

Fig. 5. Ommastraphes bartramii. Density of paralarval neon flying squid in relation to north-south sections of salinity and temperature $\left({ }^{\circ} \mathrm{C}\right.$ ) along latitudinal transects in (a) 2001, (b) 2002 and (c) 2003. Horizontal lines (red) with 2-way arrows at the top indicate the subtropical frontal zone (STFZ). $\boldsymbol{\nabla}$ and $\boldsymbol{\Delta}$ : station locations. The yellow colored parts of temperature sections correspond to the optimum spawning $\mathrm{SST}$ of 21 to $25^{\circ} \mathrm{C}$. For paralarval squid densities see Fig. 4 
Table 2. Ommastraphes bartramii. Multiple linear regression analysis with a first-autoregressive process between the survey $\ln (\mathrm{CPUE})$ for neon flying squid and 4 potential influential factors. The 9 best models are based on $\mathrm{AIC}_{\mathrm{C}}$ values; the best model is shown in bold text. $\mathrm{R}^{2}$ : coefficient of determination

\begin{tabular}{|c|c|c|c|c|c|c|}
\hline \multirow{2}{*}{ Factor 1} & \multicolumn{3}{|c|}{ Variables in model } & \multirow[t]{2}{*}{$\mathrm{R}^{2}$} & \multirow[t]{2}{*}{ Residual SE } & \multirow{2}{*}{$\mathrm{AIC}_{\mathrm{c}}$} \\
\hline & Factor 2 & Factor 3 & Factor 4 & & & \\
\hline winterSST $18^{\circ} \mathrm{C}_{t}$ & & & & 0.452 & 1.035 & 34.4 \\
\hline $\ln \left(\mathrm{CPUE}_{t-1}\right)$ & & & & 0.277 & 1.365 & 36.9 \\
\hline winterSST $18^{\circ} \mathrm{C}_{t}$ & $\ln \left(\mathrm{CPUE}_{t-1}\right)$ & & & 0.604 & 0.871 & 38.7 \\
\hline summerSST $18^{\circ} \mathrm{C}_{t}$ & $\ln \left(\mathrm{CPUE}_{t-1}\right)$ & & & 0.288 & 1.567 & 43.9 \\
\hline catch $_{t}$ & $\ln \left(\mathrm{CPUE}_{t-1}\right)$ & & & 0.278 & 1.589 & 44.1 \\
\hline winterSST $18^{\circ} \mathrm{C}_{t}$ & catch $_{t}$ & $\ln \left(\mathrm{CPUE}_{t-1}\right)$ & & 0.604 & 1.045 & 50.6 \\
\hline winterSST $18^{\circ} \mathrm{C}_{t}$ & summerSST $18^{\circ} \mathrm{C}_{t}$ & $\ln \left(\mathrm{CPUE}_{t-1}\right)$ & & 0.604 & 1.046 & 50.7 \\
\hline summerSST $18^{\circ} \mathrm{C}_{t}$ & catch $_{t}$ & $\ln \left(\mathrm{CPUE}_{t-1}\right)$ & & 0.297 & 1.857 & 55.8 \\
\hline winterSST $18^{\circ} \mathrm{C}_{t}$ & summerSST $18^{\circ} \mathrm{C}_{t}$ & $\operatorname{catch}_{t}$ & $\ln \left(\mathrm{CPUE}_{t-1}\right)$ & 0.604 & 1.307 & 74.6 \\
\hline
\end{tabular}

Table 3. Ommastraphes bartramii. Multiple linear regression analysis without a first-autoregressive process between the survey $\ln$ (CPUE) for neon flying squid and 3 potential influential factors. The best model is shown in bold text. $\mathrm{R}^{2}$ : coefficient of determination

\begin{tabular}{|c|c|c|c|c|c|}
\hline Factor 1 & $\begin{array}{l}\text { lables in model - } \\
\text { Factor } 2\end{array}$ & Factor 3 & $\mathrm{R}^{2}$ & $\begin{array}{l}\text { Residual } \\
\text { SE }\end{array}$ & $\mathrm{AIC}_{\mathrm{c}}$ \\
\hline winterSST $18^{\circ} \mathrm{C}_{t}$ & & & 0.484 & 0.938 & 35.5 \\
\hline Null & & & 0.000 & 1.617 & 37.8 \\
\hline winterSST $18^{\circ} \mathrm{C}_{t}$ & summerSST $18^{\circ} \mathrm{C}_{t}$ & & 0.493 & 1.055 & 41.3 \\
\hline winterSST $18^{\circ} \mathrm{C}_{t}$ & $\operatorname{catch}_{t}$ & & 0.484 & 1.072 & 41.5 \\
\hline $\operatorname{catch}_{t}$ & & & 0.005 & 1.809 & 42.1 \\
\hline summerSST $18^{\circ} \mathrm{C}_{t}$ & & & 0.002 & 1.815 & 42.1 \\
\hline summerSST18 $8^{\circ} \mathrm{C}_{t}$ & catch $_{t}$ & & 0.006 & 2.067 & 48.1 \\
\hline winterSST $18^{\circ} \mathrm{C}_{t}$ & summerSST $18^{\circ} \mathrm{C}_{t}$ & $\operatorname{catch}_{t}$ & 0.498 & 1.217 & 50.2 \\
\hline
\end{tabular}

(Fig. 3). For both limits, $\mathrm{AIC}_{\mathrm{c}}$ also selected the model with winterSST $18^{\circ} \mathrm{C}_{t}$ only as the best one. $\Delta \mathrm{AIC}_{\mathrm{c}}$ between the best and the second-best model (null model) was 0.53 when we used the $95 \%$ upper limit. Secondly, we excluded the data for 2000 from multiple regression analysis. The $\mathrm{AIC}_{\mathrm{c}}$ selects the null model as the best one. The second-best model was one with winterSST $18^{\circ} \mathrm{C}_{t}$ as only one predictor. $\triangle \mathrm{AIC}_{\mathrm{c}}$ between it and the best model was 0.44 . The coefficient of winterSST $18^{\circ} \mathrm{C}_{t}$ (i.e. -0.756 ) remained similar to that in the case when the estimate for 2000 was used.

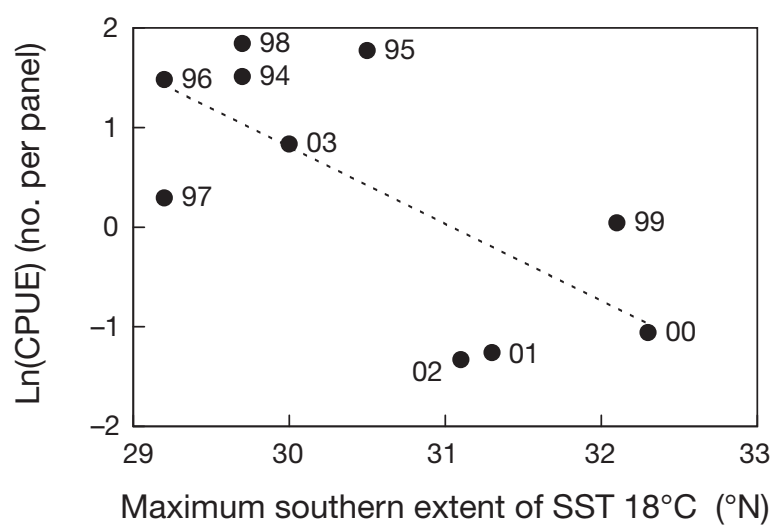

Fig. 6. Ommastraphes bartramii. Relationship between the southernmost wintertime latitude of the transition zone chlorophyll front (TZCF, as indicated by the $18^{\circ} \mathrm{C} \mathrm{SST}$ ) and yearly stock level as survey driftnet $\ln$ (CPUE) of the autumn cohort of neon flying squid. Datapoints are marked with the years 1994 to 2003 . The wintertime latitude of $18^{\circ} \mathrm{C} \mathrm{SST} \mathrm{had}$ a significant correlation with the $\ln$ (CPUE) $(\mathrm{r}=-0.70, t=$ $-2.74, \mathrm{df}=8, \mathrm{p}=0.025)$. Latitudinal positions of the $\mathrm{SST} 18^{\circ} \mathrm{C}$ (averaged between $160^{\circ} \mathrm{W}$ and $180^{\circ}$ ) in the North Pacific Ocean are derived from Bograd et al. (2004)
Thus, the winter position of the TZCF could be still more important than other potential factors, even though the 2000 data point was removed and the upper limit of the CI was used.

\section{Interannual variability of the TZCF and productivity in the STFZ}

To illustrate any differences in the oceanographic environment between the periods with high stock regime (pre-1999) and the low stock regime (1999 to 2002), we compared their monthly latitudinal extent of high chl a concentration $\left(\geq 0.2 \mathrm{mg} \mathrm{m}^{-3}\right)$ and the optimum spawning SST of 21 to $25^{\circ} \mathrm{C}$ averaged over the region bounded by $170^{\circ} \mathrm{E}$ and $150^{\circ} \mathrm{W}$ in relation to the STFZ, i.e. the main spawning/nursery ground. The optimum spawning SST for the autumn cohort of adult squid occurred at almost identical latitudinal range during both regimes, but a large difference was noticed in the high chl a concentration area in the nursery ground (Fig. 7). When the autumn cohort 
was in the juvenile stage, the high chl a concentration zone was spatially vast $\left(29\right.$ to $\left.34^{\circ} \mathrm{N}\right)$ for the high stock regime, but small $\left(32.5\right.$ to $\left.34^{\circ} \mathrm{N}\right)$ in the low stock regime. This suggests that, although the main autumn spawning ground corresponded to the STFZ in both regimes, a large portion of juvenile neon flying squid experienced a less productive environment during the low stock regime.

Besides surface chl a concentration, negative NPP anomalies were observed in the spawning/nursery ground during 1999 to 2002 (low stock regime) with reference to 1997 to 1998 and 2003 to 2006 (high and medium stock regimes) (Fig. 8). Anomalous negative NPP (less than $-50 \mathrm{mg} \mathrm{C}^{-2} \mathrm{~d}^{-1}$ ) areas occurred in the STFZ during January to March. In the main spawning/nursery ground, the proportions of anomalous negative NPP areas were only 1, 2 and $5 \%$ for October, November and December, respectively. This increased considerably to 30,43 and $56 \%$ for January, February and March, respectively. Thus, the low stock regime was characterized by shrinkage of productive habitat during the nursery period (January to March), but not during the spawning period (October to November). The anomalous negative NPP areas shifted northward during April to June in the central North Pacific Ocean.

\section{Large-scale climate changes}

The first mode of EOFs, which is equivalent to the first principal component of principal component analysis, derived from time series SLA data in the
North Pacific basin, explained about $22.7 \%$ of the total variance (Fig. 9). Time series of monthly weighing functions (EOFs), which can be used as indicators of temporal and spatial changes in geostrophic transport and vertical structure of the upper ocean, highlights variation of SLA mainly in the TZ and STFZ region as observed from the corresponding spatial pattern (Fig. 9b). A low SLA period was noticed during 1993 to 1998, which was followed by an abrupt rise in 1999 leading to a high SLA period during 1999 to 2002. From 2003 onward, a period of intermediate SLA between the previous low (1993 to 1998) and high (1999 to 2002) periods was observed in Fig. 9a. This pattern was similar to that of interannual change of the autumn cohort stock (Fig. 2). In fact, the stock level has a significant correlation $(r=-0.79, p<0.01)$ with SLA in the main spawning and nursery grounds of the autumn cohort (i.e. 30 to $34^{\circ} \mathrm{N}, 172^{\circ} \mathrm{E}$ to $140^{\circ} \mathrm{W}$ ) during spawning and nursery periods (October to March) (Fig. 10).

\section{DISCUSSION}

Our multiple linear regression analysis generally supported that winterSST $18^{\circ} \mathrm{C}_{t}$ is the best predictor to the drastic change of the stock level. However, there are still some statistical concerns. Firstly, the stock level of the current year would be influenced by the stock level of the previous year because of potential stock-recruitment relationships. Our results suggest that even if we consider the autoregressive process, the model with only winterSST $18^{\circ} \mathrm{C}_{t}$ (winter

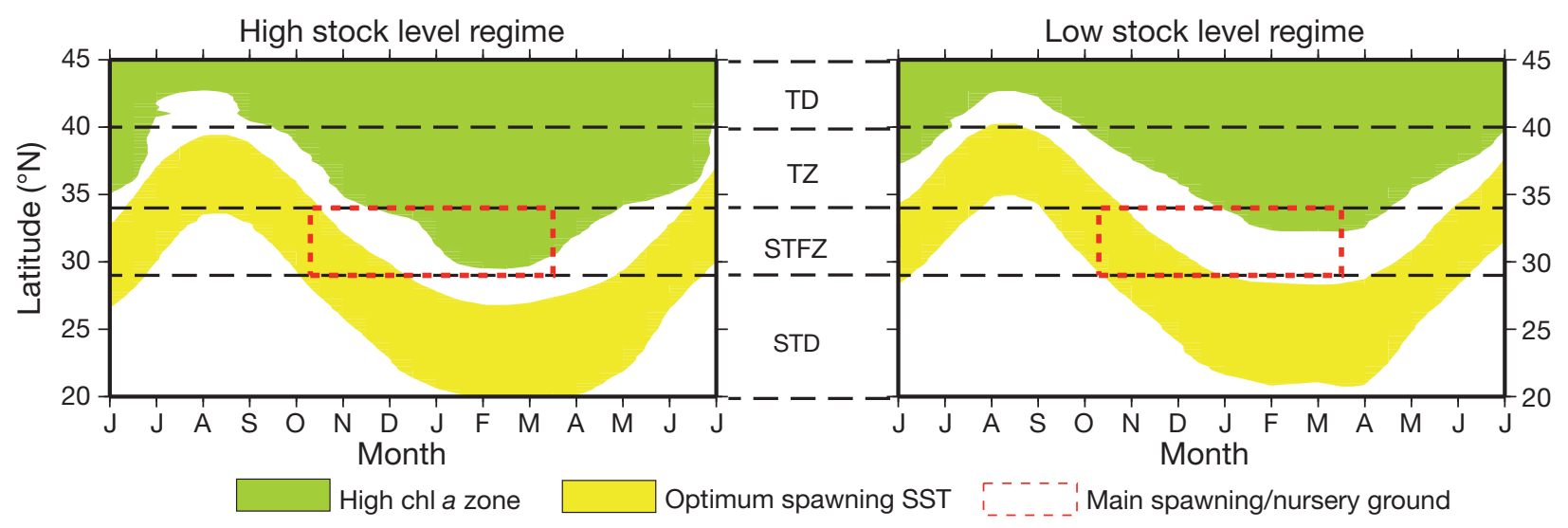

Fig. 7. Ommastraphes bartramii. Comparison of monthly meridional distributions of the high chl a zone and optimum spawning SST zone (averaged between $170^{\circ} \mathrm{E}$ and $150^{\circ} \mathrm{W}$ ) with respect to the spawning/nursery ground between high stock regime (pre-1999) and low stock regime (1999 to 2002) of the autumn cohort of neon flying squid. TD, TZ, STFZ and STD indicate the transition domain, transition zone, subtropical frontal zone and subtropical domain, respectively. Zones of high chl a concentration have chl $a \geq 0.2 \mathrm{mg} \mathrm{m}^{-3}$. The southern boundary of the high chl a area corresponds to the transition zone chlorophyll front. According to Roden (1991), the positions of the frontal zones do not vary seasonally and are relatively fixed in time and space around their climatological mean positions 

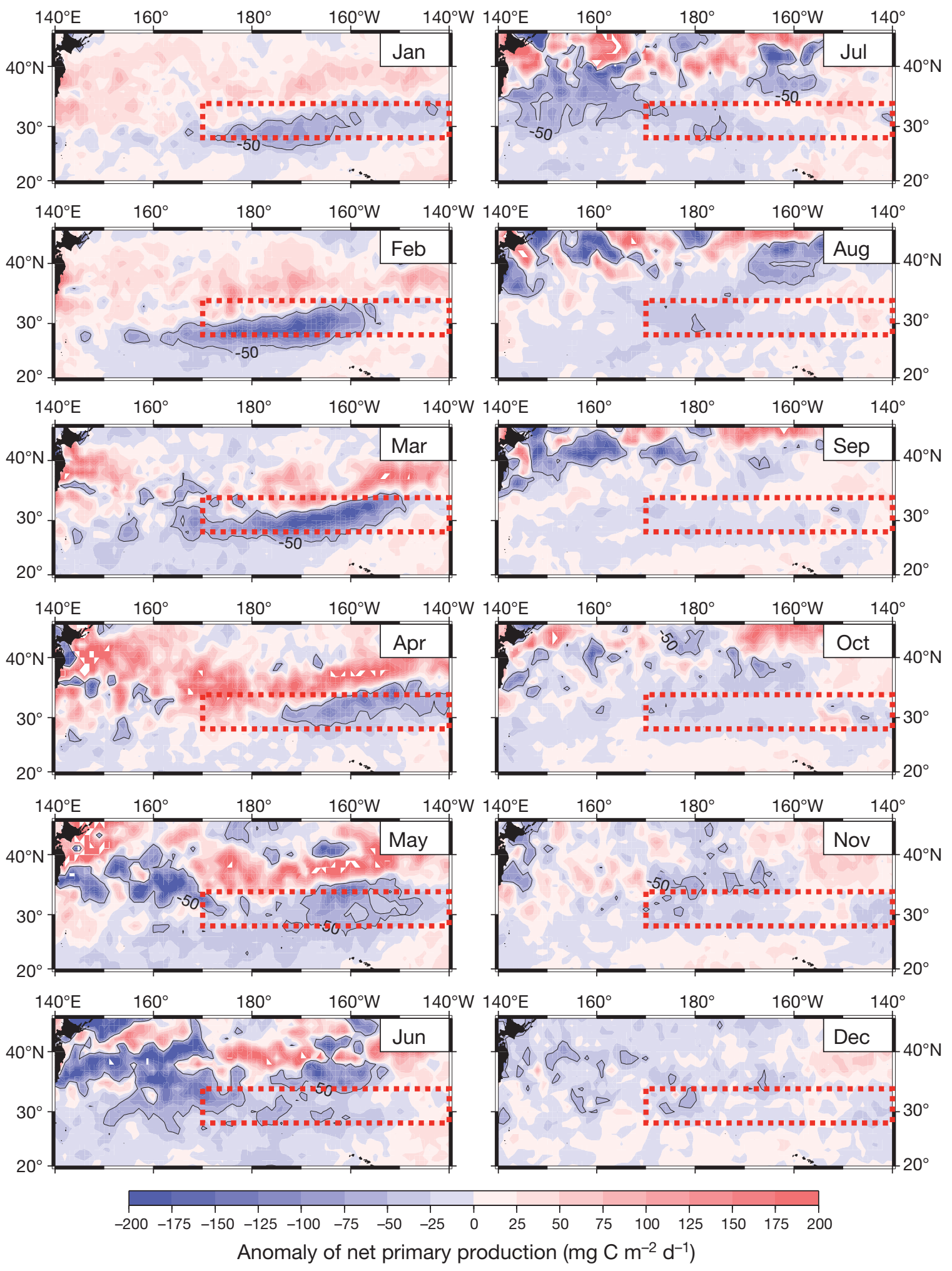

Fig. 8. Ommastraphes bartramii. Anomaly of monthly net primary productivity (NPP) in the North Pacific during January to December computed by deducting the high and medium regime (1997 to 1998 and 2003 to 2006) values from those of the low stock regime (1999 to 2002). Anomalous negative NPP (less than $-50 \mathrm{mg} \mathrm{C}^{-2} \mathrm{~d}^{-1}$ ) areas are outlined. Rectangles with red broken lines show the region where the main spawning/nursery ground for the autumn cohort of neon flying squid is formed 
(a) Time series of EOF1 of SLA

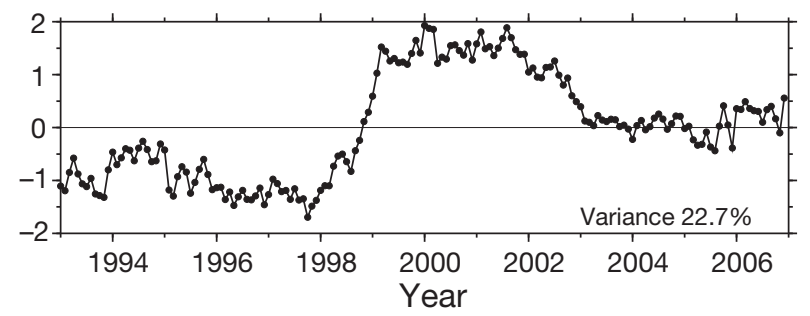

(b) Spatial pattern of EOF1 of SLA

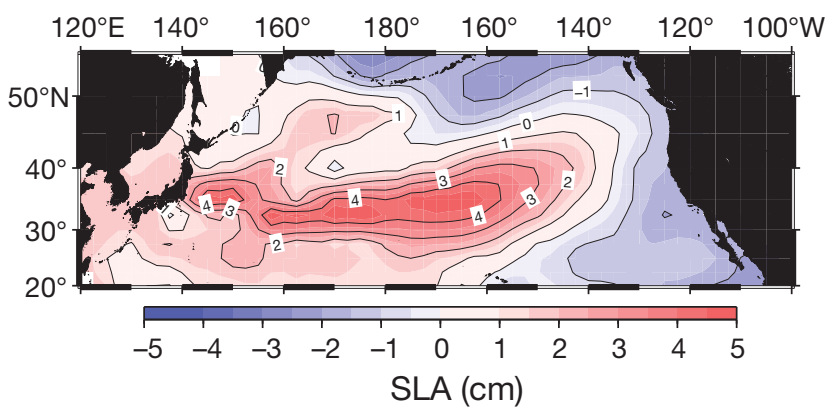

Fig. 9. (a) Time series of the first mode of the empirical orthogonal function (EOF) analysis of sea level anomaly (SLA) and (b) spatial pattern of the first mode of SLA EOF in the North Pacific. The high SLA period was observed during 1999 to 2002 and was followed by an intermediate SLA level in the STFZ and TZ

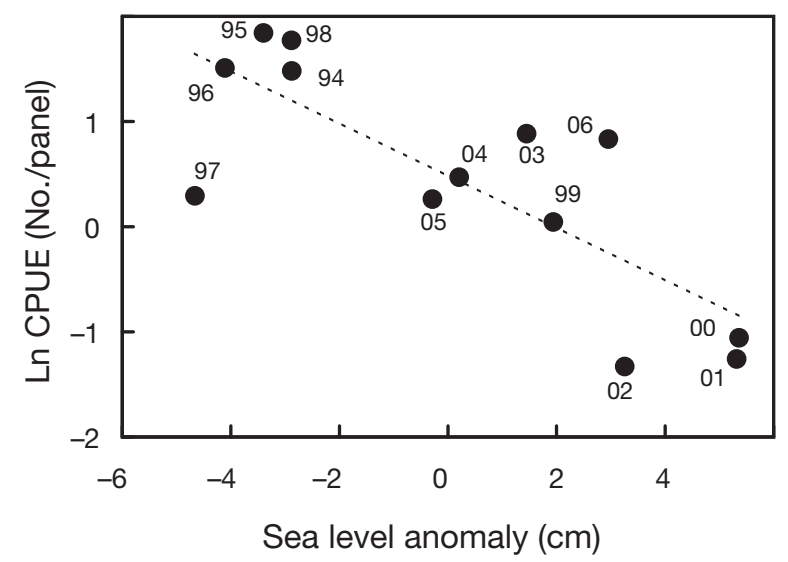

Fig. 10. Ommastraphes bartramii. Relationship between sea level anomaly (SLA) during the spawning and nursery period (October to March) and yearly stock level as survey driftnet $\ln$ (CPUE) of the autumn cohort of neon flying squid. Datapoints are marked with the years 1994 to 2006. The SLA had a significant correlation with the $\ln$ (CPUE) $(\mathrm{r}=-0.79, t=$ $-4.27, \mathrm{df}=11, \mathrm{p}=0.0013$ )

position of the TZCF) would best explain the change in the stock level of neon flying squid. Such nonsignificance of a first-order autoregressive process can be mainly attributed to poor recruitment relationships of ommastrephid squid whose life cycle is 1 yr (Bakun \& Csirke 1988). Secondly, there is a con- cern about the influence of the estimate of data for 2000 on statistical inferences. The model with winterSST $18^{\circ} \mathrm{C}_{t}$ remained the best model between the $95 \%$ upper limit and $5 \%$ lower limit of a CI for the estimate. However, when this data point (i.e. data for 2000) was excluded from the analysis, the model with winterSST $18^{\circ} \mathrm{C}_{t}$ was the second best after the null model. This may be due to the reduced statistical power to detect temporal trends in CPUE that resulted from a decrease in sample size by one. Although the scarcity of data tends to obscure the conclusion, we could accept the plausible strong influence of winterSST $18^{\circ} \mathrm{C}_{t}$ in the overall context of our analysis.

The high SLA period of 1999 to 2002 was characterized by the abrupt increase in SLA in 1999 in the STFZ and the transition zone (Fig. 9). This represented an increase in heat content and depth of the top of the thermocline/nutricline and subsequent reduced enhancement of productivity (Howell \& Polovina 2005, Kahru et al. 2007), which was reflected by a northward shift of the wintertime TZCF (Polovina \& Howell 2005). This could be the potential cause for significant reduction in the area of high primary productivity within the STFZ (i.e. the main nursery ground for neon flying squid) during winter (January to March). Correspondingly, the stock level of neon flying squid was much lower during this period. The lower stock level, therefore, can be attributed to a northward shift of the wintertime TZCF and consequent shrinkage of the productive nursery ground.

We hypothesize a framework through which the dynamics of the TZCF might influence the stock level of squid and in which the productive area near and north of the TZCF is likely to affect the food chain providing an enhanced feeding regime for squid, which is supported by previous studies. Firstly, Young \& Hirota (1999) reported that copepods were abundant around a SST of ca. $19^{\circ} \mathrm{C}$ during winter, which closely corresponds to the TZCF (Bograd et al. 2004). Secondly, Seki \& Bigelow (1993) showed that larval and juvenile Pacific pomfret Brama japonica are abundant along the wintertime SST of ca. $18^{\circ} \mathrm{C}$. These prerecruit pomfret reportedly feed on planktonic crustaceans. Thirdly, the prey of juvenile neon flying squid was small fish in the STFZ during winter (Yasui 1981). Therefore, primary productivity could lead to favorable feeding habitat for squid in the STFZ. Baker et al. (2007) also reported that the wintertime TZCF position represents a possible mechanism for variable juvenile monk seal survival through the food web in the northern portion of the northwestern Hawaiian Is- 
lands ecosystem, which is located around the southern boundary of the STFZ. Thus, the dynamics of the TZCF influence not only productivity but also the food web, through which prey availability for juvenile neon flying squid changes.

In the period from 1999 to 2002 NPP showed the distinct negative anomaly in the STFZ during January and March (Fig. 8). Given that the main hatching months of the autumn cohort of squid are October and November (Chen \& Chiu 2003), their age during January and March corresponds to ca. 1+ to $5+$ mo of age, suggesting that this juvenile period may be critical to affect the recruitment level. This juvenile period is characterized by rapid growth for this species (Yatsu \& Mori 2000). Hence, in years when shrinkage of the food-rich area occurred within the STFZ during this important development period, a high proportion of individuals of the autumn cohort cannot utilize the food-rich habitat, which may have led to considerably slower growth. This could lead to a decrease in stock recruitment of this cohort for 2 reasons. Firstly, slow-growing juveniles are smaller than fast-growing juveniles of the same age and thus more vulnerable to predators (the bigger-is-better hypothesis; Miller et al. 1988). An important predator for this species is swordfish Xiphias gladius, which congregate in the STFZ during winter and feed mainly on the neon flying squid including juveniles (Watanabe et al. 2009). Secondly, slow-growing juveniles cannot attain larger body size to become the LL group (the autumn cohort; sensu Murata 1990) by the time this group starts the northward migration in spring. Even if slow-growing individuals try to migrate northward together with the LL group, the former may not be able to follow the latter because of their lower relative swimming capacity, given that swimming velocities are expressed as body lengths per second (Bartol et al. 2001). Based on age estimates from statoliths (Chen \& Chiu 2003) a high proportion of individuals that hatched in autumn (October and November) end up joining the $\mathrm{L}$ and $\mathrm{S}$ group (winter cohort) for the rest of their life, most probably due to poor prey conditions leading to slowgrowing juveniles.

There is a possibility that the anomalous climate conditions during 1999 to 2002 might also have affected the winter cohort in the central North Pacific Ocean. A distinct negative anomalous NPP area observed in the STFZ in winter (January to March) shifted northward in the TZ during spring (April to June) in the central North Pacific (Fig. 8). Northward movement of this anomalous NPP area coincided with the northward migration pattern of the winter cohort spatially and temporally (Ichii et al. 2004, 2009). This suggests a possibility that the occurrence of reduced NPP during 1999 to 2002 affected feeding regimes adversely for not only the autumn cohort (in January to March) but also the winter cohort (in April to June) during their juvenile period.

Furthermore, in the western North Pacific Ocean, a distinct negative anomalous NPP area also occurred and shifted northward from around the Kuroshio extension current $\left(\mathrm{ca} .34^{\circ} \mathrm{N}\right)$ to the subarctic front (ca. $40^{\circ} \mathrm{N}$ ) during May and July in the period from 1999 to 2002. This northward shift of the negative NPP area coincided with the northward migration pattern of western winter-spring cohort (Yatsu 1992, Murata \& Hayase 1993). The occurrence of the reduced NPP, in addition to annual catches larger than $100000 \mathrm{t}$ of the winter-spring cohort by the Chinese jigging fishery, may have been a factor in the lower stock abundance (Cao et al. 2009) of the western winter-spring cohort of neon flying squid during the anomalous period.

Regarding other Ommastrephidae, Waluda et al. (2001) showed that the paralarval stage (age of $0+$ mo) may be a critical period for recruitment of Illex argentinus. Oceanographic conditions during the paralarval period are characterized with interannual variability in the confluence zone between the Brazil and Falkland currents. Mori (2006) suggested that ca. $1+$ to $4+$ mo of age may be a critical period for the winter cohort of Todarodes pacificus. T. pacificus juveniles during this period inhabit the Kuroshio Current area off southern Japan and the downstream Kuroshio-Oyashio transition region, which are characterized by large spatial and temporal variability in the environment (Yasuda 2003, Ishikawa et al. 2004). Thus, the spawning and nursery period of ommastrephid squid, for which habitats exhibit large interannual variability, are likely to be critical periods that determine the level of recruitment.

The stock level of the autumn cohort of neon flying squid from 2003 did not return to the previous level of the high stock regime (pre-1999 period) after going through the low stock regime (1999 to 2002) (Fig. 2). Baker et al. (2007) also showed that the survival rate of juvenile monk seals from 2003 onward tended to be lower than the previous high level observed in the pre-1999 period. Similar to the time series of first EOF mode, SLA in the period 2003 to 2006 corresponded to an intermediate level between the low and high stock regimes in the TZ and STFZ region, suggesting that this period may be a new regime. Considering identical interannual variability 
patterns of the autumn cohort stock and SLA and the significant correlation between them (Fig. 10), the survival of juvenile squid could be also strongly affected by interannual variations of the upper ocean structure in the STFZ.

The bottom-up effect of the climate shift showed that neon flying squid respond quickly to large-scale environmental changes. Productivity in the STFZ (main nursery ground), through the food chain and in $\mathrm{SSH}$, which reflects changes in the depth of the thermocline and, hence, may have significant ecosystem implications, were considered to be the important oceanographic conditions that affected recruitment of the neon flying squid. Thus, neon flying squid can act as real time ecosystem indicators and productivity integrators (Jackson \& O'Dor 2007).

Acknowledgements. We thank M. Okazaki for help with the generic mapping tools. We also thank K. Taki, M Kiyota, T. Shimose, H. Watanabe and S. Yonezaki for their critical readings of the manuscript. The constructive comments and suggestions from 4 anonymous reviewers are greatly appreciated. This study was supported by the project on the evaluation of status of international fishery resources by the Fisheries Agency of Japan.

\section{LITERATURE CITED}

Baker JD, Polovina JJ, Howell EA (2007) Effect of variable oceanic productivity on the survival of an upper trophic predator, the Hawaiian monk seal Monachus schauinslandi. Mar Ecol Prog Ser 346:277-283

Bakun A, Csirke J (1988) Environmental processes and recruitment variability. In: Rodhouse PG, Dawe EG, O'Dor RK (eds) Squid recruitment dynamics. FAO Fish Tech Pap 376, Rome, p 105-120

Bartol IK, Mann R, Patterson MR (2001) Aerobic respiratory costs of swimming in the negatively buoyant brief squid Lolliguncula brevis. J Exp Biol 204:3639-3653

> Behrenfeld MJ, Falkowski PG (1997) Photosynthetic rates derived from satellite-based chlorophyll concentration. Limnol Oceanogr 42:1-20

Bograd SJ, Foley DG, Schwing FB, Wilson C and others (2004) On the seasonal and interannual migration of the transition zone chlorophyll front. Geophys Res Lett 31: L17204, doi:10.1029/2004GL020637

Bower JR (1994) Distribution of paralarvae of the squid Ommastrephes bartramii near the Hawaiian Archipelago. MS thesis, University of Hawaii, Honolulu, HI

Bower JR (1996) Estimated paralarval drift and inferred hatching sties for Ommastrephes bartramii (Cephalopoda:Ommastrephidae) near the Hawaiian Archipelago. Fish Bull 94:398-411

Bower JR, Ichii T (2005) The red flying squid (Ommastrephes bartramii): a review of recent research and the fishery in Japan. Fish Res 76:39-55

Burnham KP, Anderson DR (2002) Model selection and inference: a practical information-theoretic approach. 2nd edn. Springer-Verlag, New York, NY
Cao J, Chen X, Chen Y (2009) Influence of surface oceanographic variability on abundance of the winter-spring cohort of neon flying squid Ommastrephes bartramii in the NW Pacific Ocean. Mar Ecol Prog Ser 381:119-127

Chen C, Chiu T (2003) Variations of life history parameters in two geographical groups of the neon flying squid, Ommastrephes bartramii, from the North Pacific. Fish Res 63:349-366

> Chen XJ, Liu BL, Chen Y (2008) A review of the development of Chinese distant-water squid jigging fisheries. Fish Res 89:211-221

Feldman GC, McClain CR (2007) Ocean color web. SeaWiFS 5.2, NASA Goddard Space Flight Center, Kuring N, Bailey SW (eds), September 7, 2007. http://oceancolor.gsfc. nasa.gov/ (accessed 1 June 2010)

Harman RE, Young RE (1985) The larvae of ommastrephid squids (Cephalopoda, Teuthoidea) from Hawaiian waters. Vie Milieu 35:211-222

Hokkaido University (1980-2000) Data record and oceanographic observations and exploratory fishing, nos. 22-43. Faculty of Fisheries, Hokkaido University, Hakodate

Howell E, Polovina J (2005) Central North Pacific. In: Boldt JL (ed) Fisheries and the environment: Ecosystem indicators for the North Pacific and their implications for the stock assessment. AFSC processed report 2005-04. Alaska Fisheries Science Center, Anchorage, AK, p 9-13

Ichii T, Mahapatra K, Sakai M, Inagake D, Okada Y (2004) Differing body size between the autumn and the winterspring cohorts of neon flying squid (Ommastrephes bartramii) related to the oceanographic regime in the North Pacific: a hypothesis. Fish Oceanogr 13:295-309

> Ichii T, Mahapatra K, Okamura H, Okada Y (2006) Stock assessment of the autumn cohort in the North Pacific based on past large-scale high sea driftnet fishery data. Fish Res 78:286-297

Ichii T, Mahapatra K, Sakai M, Okada Y (2009) Life history of the neon flying squid: effect of the oceanographic regime in the North Pacific Ocean. Mar Ecol Prog Ser 378:1-11

Ishikawa Y, Awaji T, Komori N, Toyoda T (2004) Application of sensitivity analysis using an adjoint model for shortrange forecasts of the Kuroshio Path south of Japan. J Oceanogr 60:293-301

Jackson GD, O'Dor RK (2007) Perspectives and discussions (squid - the new ecosystem indicators). In: Olson RJ, Young JW (eds) The role of squid in open ocean ecosystems. Reports of a GLOBEC-CLIOTOP/PFRP workshop, 16-17 November 2006, Honolulu, Hawaii, USA. GLOBEC Report 24, Plymouth, p 78-80

> Kahru M, Fiedler PC, Gille ST, Manzano M, Mitchell BG (2007) Sea level anomalies control phytoplankton biomass in the Costa Rica dome area. Geophys Res Lett 34: L22601, doi:10.1029/2007GL031631

Miller TJ, Crowder LB, Rice JA, Marschall EA (1988) Larval size and recruitment mechanisms in fishes: toward a conceptual framework. Can J Fish Aquat Sci 45:1657-1670

Minobe S (2004) Updated assessments of the 1998/99 climate change over the North. Pacific. In: Mawatari SF, Okada H (eds) Neo-Science of Natural History: Integration of Geoscience and Biodiversity Studies: Proceedings of International Symposium on 'Dawn of a New Natural History-Integration of Geoscience and Biodiversity Studies', March 5-6, 2004, Sapporo. Graduate School of Science, Hokkaido University, p 103-106. http://hdl. handle.net/2115/38513 
Morel A, Berthon JF (1989) Surface pigments, algal biomass profiles, and potential production of the euphotic layer: relationships reinvestigated in view of remote-sensing applications. Limnol Oceanogr 34:1545-1562

Mori K (2006) Early life ecology and mechanism of population dynamics of the winter cohort of Todarodes pacificus. PhD thesis, Hokkaido University

Murata M (1990) Oceanic resources of squids. Mar Behav Physiol 18:19-71

Murata M, Hayase S (1993) Life history and biological information on flying squid (Ommastrephes bartramii) in the North Pacific Ocean. Int North Pac Fish Comm Bull 53: 147-182

Murata M, Nakamura Y (1998) Seasonal migration and diel migration of the neon flying squid, Ommastrephes bartramii, in the North Pacific. In: Okutani T (ed) International symposium on large pelagic squids. Japan Marine Fishery Resources Research Center, Tokyo, p13-30

Peterson WT, Schwing FB (2003) A new climate regime in northeast pacific ecosystems. Geophys Res Lett 30:1896, doi:10.1029/2003GL017528

Polovina JJ, Howell E (2005) Recent ecosystem changes in the Central North Pacific. In: King JR (ed) Report of the study group on fisheries and ecosystem responses to recent shifts. PICES Sci Rep 28:59-64

Polovina JJ, Kobayashi DR, Parker DM, Seki MP, Balazs GH (2000) Turtles on the edge: movement of loggerhead turtles (Caretta caretta) along oceanic fronts spanning longline fishing grounds in the central North Pacific, 19971998. Fish Oceanogr 9:71-82

Polovina JJ, Howell E, Kobayashi DR, Seki MP (2001) The Transition Zone Chlorophyll Front, a dynamic, global feature defining migration and forage habitat for marine resources. Prog Oceanogr 49:469-483

Roden GI (1991) Subarctic-subtropical transition zone of the North Pacific: large-scale aspects and mesoscale structure. NOAA NMFS Tech Rep 105:1-38

Roper CFE, Sweeney MJ, Nauen CE (1984) FAO species catalogue. Vol 3: cephalopods of the world. An annotated and illustrated catalogue of species of interest to fisheries. FAO Fish Synop 125, Rome

Saito K (1994) Distribution of paralarvae of Ommastrephes bartramii and Eucleoteuthis luminosa in the eastern waters off Ogasawara Islands. Bull Hokkaido Natl Fish Res Inst 58:15-23 (in Japanese with English title and abstract)

Saito H, Kubodera T (1993) Distribution of Ommastrephid rhynchoteuthion paralarvae (Mollusca, Cephalopoda) in the Kuroshio Region. In: Okutani T, O'Dor RK, Kubodera $\mathrm{T}$ (eds) Recent advances in cephalopod fisheries biology. Tokai University Press, Tokyo, p 457-466

Sakurai Y, Kiyofuji H, Saitoh S, Goto T, Hiyama Y (2000) Changes in inferred spawning areas of Todarodes pacificus (Cephalopoda: Ommastrephidae) due to changing environmental conditions. ICES J Mar Sci 57:24-30

Seki MP, Bigelow KA (1993) Aspects of the life history and ecology of the Pacific pomfret Brama japonica during winter occupation of the Subtropical Frontal Zone. Int

Editorial responsibility: Konstantinos Stergiou, Thessaloniki, Greece
North Pac Fish Comm Bull 53:273-283

Takagi K (1975) A non-selective salmon gillnet for research operations. Int North Pac Fish Comm Bull 32:13-33

> Wakabayashi T, Suzuki N, Sakai M, Ichii T, Chow S (2006) Identification of ommastrephid squid paralarvae collected in northern Hawaiian waters and phylogenetic implications for the family Ommastrephidae using mtDNA analysis. Fish Sci 72:494-502

- Waluda C, Rodhouse P, Podesta G, Trahan P, Pierce G (2001) Surface oceanography of the inferred hatching grounds of Illex argentinus (Cephalopoda: Ommastrephidae) and influences on recruitment variability. Mar Biol 139: $671-679$

Watanabe H, Kubodera T, Yokawa K (2009) Feeding ecology of the swordfish Xiphias gladius in the subtropical region and transition zone of the western North Pacific. Mar Ecol Prog Ser 396:111-122

- Yasuda I (2003) Hydrographic structure and variability in the Kuroshio-Oyashio transition area. J Oceanogr 59: 389-402

Yasui K (1981) Report of a feasibility study on the development of squid jigging grounds in North Pacific in the fiscal 1979. Japan Marine Resources Research Center, Tokyo (in Japanese)

Yatsu A (1992) Distribution of flying squid, Ommastrephes bartramii, in the North Pacific based on a jigging survey, 1976-83. Bull Natl Res Inst Far Seas Fish 29:13-37 (in Japanese with English summary)

Yatsu A, Mori J (2000) Early growth of the autumn cohort of neon flying squid, Ommastrephes bartramii, in the North Pacific. Fish Res 45:189-194

Yatsu A, Hiramatsu K, Hayase S (1993) Outline of the Japanese squid driftnet fishery with notes on the by-catch. Int North Pac Fish Comm Bull 53:5-24

Yatsu A, Midorikawa S, Shimada T, Uozumi Y (1997) Age and growth of the neon flying squid, Ommastrephes bartramii, in the North Pacific Ocean. Fish Res 29:257-270

Yatsu A, Tanaka H, Mori J (1998) Population structure of the neon flying squid, Ommastrephes bartramii, in the North Pacific Ocean. In: Okutani T (ed) International symposium on large pelagic squids. Japan Marine Fishery Resources Research Center, Tokyo, p 31-48

Yatsu A, Watanabe T, Mori J, Nagasawa K and others (2000) Interannual variability in stock abundance of the neon flying squid, Ommastrephes bartramii, in the North Pacific Ocean during 1979-1998: impact of driftnet fishing and oceanographic conditions. Fish Oceanogr 9: 163-170

Young RE, Hirota J (1990) Description of Ommastrephes bartramii (Cephalopoda: Ommastrephidae) paralarvae with evidence for spawning in Hawaiian waters. Pac Sci 44:71-80

Young RE, Hirota J (1999) Year 3 progress report and a request for supplemental funds for year 4 . Aspects of the ecology of the red squid Ommastrephes bartramii, a potential target for a major Hawaiian fishery. www. soest.hawaii.edu/PFRP/pdf/young99.pdf (accessed 16 July 2011)

Submitted: June 3, 2010; Accepted: August 25, 2011 Proofs received from author(s): November 1, 2011 